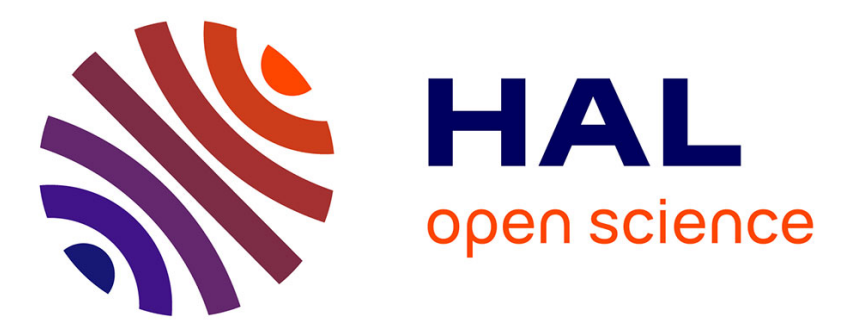

\title{
Flow and Discharge Development in an Argon Atmospheric Pressure Plasma Jet Observed by ICCD and PLIF Imaging
}

\author{
S. Iseni, S. Reuter, A. Schmidt-Bleker, K. Weltmann
}

\section{- To cite this version:}

S. Iseni, S. Reuter, A. Schmidt-Bleker, K. Weltmann. Flow and Discharge Development in an Argon Atmospheric Pressure Plasma Jet Observed by ICCD and PLIF Imaging. IEEE Transactions on Plasma Science, 2014, 42 (10), pp.2458-2459. 10.1109/TPS.2014.2321226 . hal-02270236

\section{HAL Id: hal-02270236 \\ https://hal.science/hal-02270236}

Submitted on 26 Jun 2021

HAL is a multi-disciplinary open access archive for the deposit and dissemination of scientific research documents, whether they are published or not. The documents may come from teaching and research institutions in France or abroad, or from public or private research centers.
L'archive ouverte pluridisciplinaire HAL, est destinée au dépôt et à la diffusion de documents scientifiques de niveau recherche, publiés ou non, émanant des établissements d'enseignement et de recherche français ou étrangers, des laboratoires publics ou privés. 


\title{
Flow and Discharge Development in an Argon Atmospheric Pressure Plasma Jet Observed by ICCD and PLIF Imaging
}

\author{
Sylvain Iseni, Stephan Reuter, Ansgar Schmidt-Bleker, and Klaus-Dieter Weltmann
}

\begin{abstract}
In this paper, a megahertz atmospheric pressure plasma jet is investigated regarding its discharge pattern in correlation with the flow. Single-shot imaging shows plasma streamer development in a flow pattern determined by turbulent interaction with the atmosphere. Planar laser-induced fluorescence imaging on hydroxyl shows the flow pattern. The discharge pattern is streamerlike. Here, it can be observed that the streamer exhibits a hook-like structure at the end, which might also be attributed to the gas flow pattern.
\end{abstract}

Index Terms-Atmospheric-pressure plasmas, measurement by laser beam, optical imaging, plasma diagnostics.

$\mathbf{I}$ $\mathrm{N}$ NATURAL sciences, observations of phenomena have always been the motivation to understand the physical environment. For instance, in the history of ionized gases, Sir William Crookes reported for the first time the observation of light emitted by a discharge in noble gases [1]. Similarly observational, in this paper, a radio-frequency (RF) atmospheric pressure argon plasma jet (kinpen, neoplas $\mathrm{GmbH}$, Germany) has been investigated by means of imaging techniques. Jet plasma sources have proven to be suitable for biomedical application and eukaryotic cell activationinduced wound healing [2], [3]. The plasma jet investigated in this paper is fed with 3-slm argon, and is operated with roughly $1-\mathrm{MHz}$ excitation frequency. The jet nozzle is circular, and has a diameter of $1.6 \mathrm{~mm}$. The jet generates reactive oxygen and nitrogen species when interacting with the surrounding atmosphere [4], [5]. In this paper, the spatial distribution of hydroxyl used to resemble the flow pattern of the plasma effluent is investigated with planar laser-induced

Manuscript received November 2, 2013; revised January 17, 2014; accepted February 21, 2014. This work was supported by the Federal German Ministry of Education and Research under Grant 03Z2DN12 through the Plasmatis EZE Group.

S. Iseni, S. Reuter, and A. Schmidt-Bleker are with the Centre for Innovation Competence Plasmatis, Greifswald 17489, Germany (e-mail: sylvain.iseni@inp-greifswald.de; stephan.reuter@inp-greifswald.de; ansgar.schmidt-bleker@inp-greifswald.de).

K.-D. Weltmann is with the Leibniz Institute for Plasma Science and Technology, INP Greifswald e.V., Greifswald 17489, Germany (e-mail: weltmann@inp-greifswald.de).

Digital Object Identifier 10.1109/TPS.2014.2321226 fluorescence (PLIF) spectroscopy. The $\mathrm{OH}$ molecule produced within the plasma jet originates from water impurities in the discharge. The results presented here are related to the spatial distribution of reactive species, such as the $\mathrm{OH}$ molecule [Fig. 1 (right)]. Furthermore, the spatial distribution of the discharge during one excitation period [Fig. 1 (left)] is presented.

Fig. 1 (left) shows a single-shot discharge emission (250-800 nm) recorded with a charge-coupled device camera Imager Pro X (LaVision GmbH, Germany) combined with an external gated image intensifier (Intensified Relay Optics). The intriguing character of this picture is the hook-like shape at the end of the discharge. It has been shown recently that turbulent flow is strongly considered to be the origin of this discharge propagation character [6]. Fig. 1 (right) shows a spatial distribution of the $\mathrm{OH}$ fluorescence observed by singleshot PLIF, which interestingly occurs to have a similar pattern as the hook-shaped discharge propagation. The images in the present case are taken in different RF cycles, and consequently, only a qualitative observation of the similarity in shape can be made. The hook features, however, appear in both emission and fluorescence at different distances to the nozzle so that it can be safely assumed that the occurrence of both features within one cycle is linked. Due to the nozzle geometry, the gas flow is turbulent and from distances of about $4 \mathrm{~mm}$, significant mixing with ambient is occurring. It is here, where branching and hook structures can be observed.

These observations on plasma jets are necessary to control the discharge regarding applications, for instance, surface modification or plasma medicine. In addition, the stochastic nature of density fields must be considered when evaluating experimental data and computer simulations on turbulent atmospheric pressure plasma jets obtained on time scales not significantly shorter than the Kolmogorov time scale, which describes the shortest time scale relevant for mixing in a turbulent flow [7].

To summarize, in this paper, PLIF measurements on $\mathrm{OH}$ show the flow pattern, which exhibits turbulent properties. A single-shot image of the discharge pattern shows a streamer-like property, which seems to be coinciding with the $\mathrm{OH}$ flow pattern. The study will help to understand fundamental mechanisms of discharge propagation and development. 


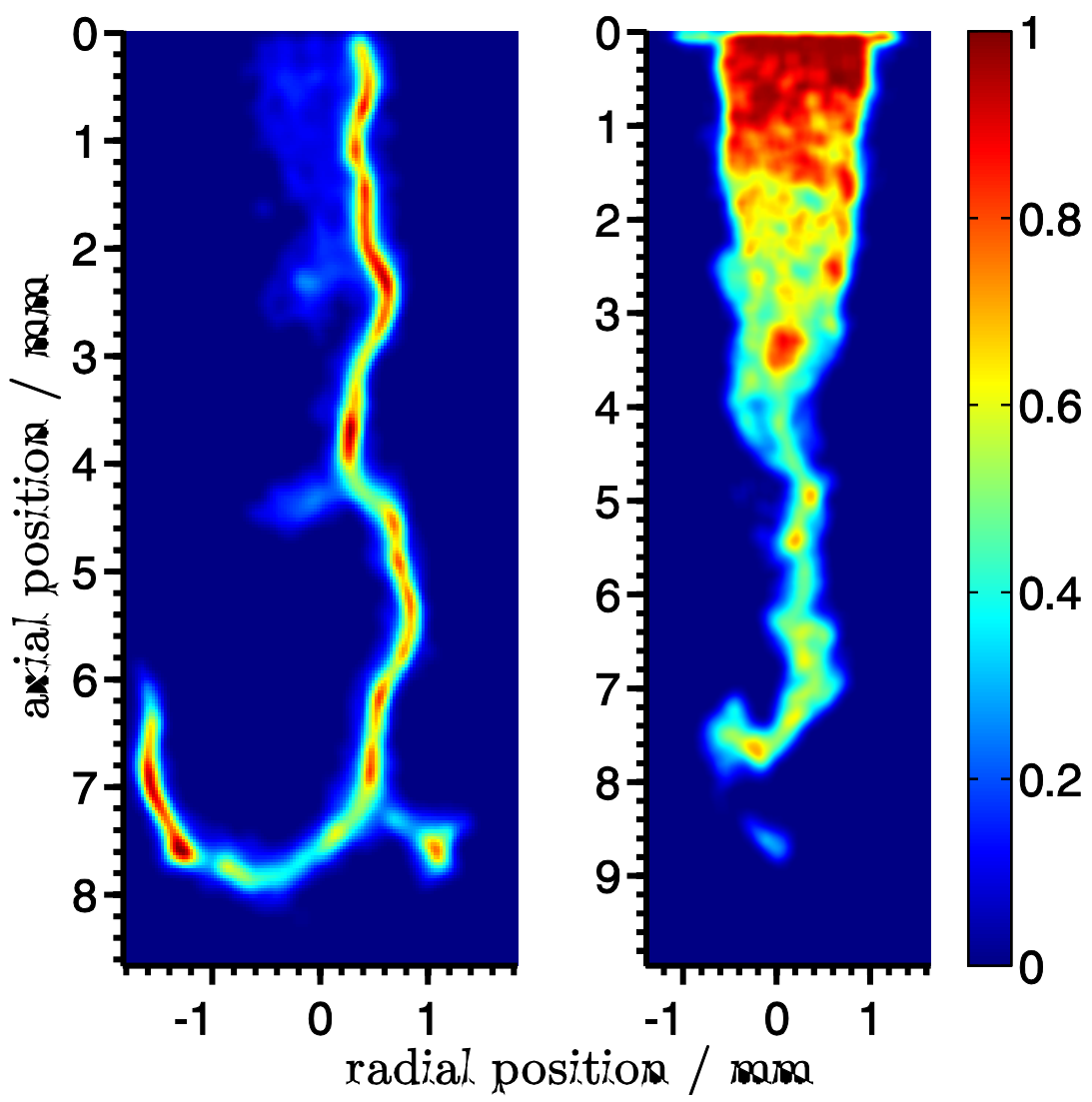

Fig. 1. ICCD pictures over one excitation period of an RF atmospheric pressure plasma jet fed with 3-slm argon. The jet nozzle is located at an axial distance of zero. Left: spontaneous radiative emissions $(250-800 \mathrm{~nm})$ depict the streamer propagation and 1.0- $\mu$ s exposure time single-shot. Right: single-shot space resolved PLIF signal of $\mathrm{OH}$ molecules generated by the plasma due to dissociation of water impurities in the feed gas.

\section{REFERENCES}

[1] W. Crookes, "The Bakerian lecture: On the illumination of lines of molecular pressure, and the trajectory of molecules," Philosoph. Trans. Roy. Soc. London, vol. 170, pp. 135-164, Jan. 1879.

[2] K.-D. Weltmann et al., "Atmospheric pressure plasma jet for medical therapy: Plasma parameters and risk estimation," Contrib. Plasma Phys., vol. 49, no. 9, pp. 631-640, Oct. 2009.

[3] L. Bundscherer et al., "Impact of non-thermal plasma treatment on MAPK signaling pathways of human immune cell lines," Immunobiology, vol. 218, no. 10, pp. 1248-1255, Oct. 2013.
[4] S. Reuter et al., "Detection of ozone in a $\mathrm{MHz}$ argon plasma bullet jet," Plasma Sources Sci. Technol., vol. 21, no. 3, p. 034015, 2012.

[5] S. Reuter et al., "From RONS to ROS: Tailoring plasma jet treatment of skin cells," IEEE Trans. Plasma Sci., vol. 40, no. 11, pp. 2986-2993, Nov. 2012.

[6] S. Iseni et al., "Atmospheric pressure streamer follows the turbulent argon air boundary in a $\mathrm{MHz}$ argon plasma jet investigated by $\mathrm{OH}$-tracer PLIF spectroscopy," J. Phys. D, Appl. Phys., vol. 47, no. 15, p. 152001, 2014.

[7] S. B. Pope, Turbulent Flows. Cambridge, U.K.: Cambridge Univ. Press, 2000. 